\title{
Dynamics of a Population of Field Mouse
}

\author{
Michel TREUSSIER ${ }^{1}$
}

\begin{abstract}
Treussier M., 1977: Dynamics of a population of field mouse. Acta theriol., 22, 12: 207-214 [With 2 Figs.].

The demographical data concern a field mouse, Apodemus sylvaticus ( $\mathrm{L}$ in n a e us, 1758) population in a boxwood pine-forest in 1972 and 1973. To carry on this study, "current (or »time-specific«) life-tables (which followed the evolution of various cohorts) were used. On the other hand, as we killed the captured animals, we got precise information on the sexual activity and on the age of the animals. The density was very low during the 2 summers. It was much higher in autumn and in spring. A ceasing of reproduction at the end of autumn is proved; another ceasing at the end of winter-beginning of spring is supposed. The young were born between May and October as well as in winter. The possibility of migrations is not to be put aside.

[Lab. Ecol. Biogéog. des Vert. terr. (E.P.H.E.) F-34060 Montpellier-Cedex, France].
\end{abstract}

\section{INTRODUCTION}

An ecological study using standard lines of traps for small mammals (S pitz, et al., 1974) was carried out from the Aigoual to the Causse Méjean (Massif Central, south of France) in 1972 and 1973. The main characteristics of distribution and the biotope of some species are defined in another paper (Treussier, 1975). The aim of this paper concerns the dynamics of a population of field mice, Apodemus sylvaticus ( $\mathrm{L}$ in$n$ a e us, 1758).

\section{MATERIAL AND METHODS}

As the trapped animals were not released and especially because of the way in which the study of the various areas of vegetation was carried on, it was not possible to obtain for each site the number of data required for a long-term demographical study. It would have been necessary to conduct a regular trapping in a few study areas. This was partially realized in some places, but as the number of captures during most of the trapping periods was small, a through treatment of the results was not possible. Only the field mice trapped in a forest of Pinus

${ }_{1}$ Present address: Laboratoire de la Faune Sauvage et de Cynégétique C.N.R.Z. F-78350 Jouy-en-Josas, France 
silvestris with a boxwood (Buxus sempervirens) underwood could be taken into account and the overall trappings in this forest could reasonably be considered as one study area. This pine forest, on the south mountain slope of the Causse Noir represents a stage of the colonization of a boxwood heath (eroded by sheep grazing) by a forest of white cak (Quercus pubescens).

The age structure was established on the basis of the eye-lens weight (Le Lo u a r n, 1971, unpubl. results). To analyse the population, time specific (current) life-tables were used ( $\mathrm{E}$ ber hardt, 1971).

\section{RESULTS}

On figure 1, six sections of the over one month old field mice in the hoxwood-pine forest of Roquedols are given. These sections may be considered as instantaneous representations of the age-class structure of the population. The class of the less than one month old animals is. excluded for their probability of capture is by far lower than that of older field mice. The limits of the classes considered are one, two, four. six, nine and twelve months. Each age-class defines for each section an easily representative cohort. The age-class corresponding to such a cohort is represented at the next section ${ }^{2}$.

The part of each cohort in the population is indicated in absolute value (not in percentage) by the numbers of field-mice of the cohort living on an area of ten hectares of pine-forest at the time when the trapping was conducted.

Figure 1 shows a population essentially composed, in mid-July 1972 cf more than four months old animals, born between October 1971 and March 1972. The number of field-mice of this generation remained large till October 1972. The animals born between March and June 1972 did not seem to play a great part. They were scarce and seemed to disappear during the summer. In November, the whole population was renewed. The population was mainly composed of animals born in August and September. It was not recovered at the beginning of May 1973 but a small part of it reappeared a month later (immigration? uncertain data at this age?). The population of this period was more than twice less dense than in November and was constituted of a generation born between, November 1972 and March 1973. Then the density goes on decreasing till the beginning of August 1973 where it became lower than in July 1972. It was only at this period that we can assume that a definite appearance of young animals born in June was recorded. The structure

\footnotetext{
2 Let us notice that if the lens-weight curve which has been used for age determination has been elaborated from a field mouse population of the Paris region many reasons justify its utilization for the field mice of the Causses (Le Lou a n, l.c.)
} 
and the volume of the population one year before were almost found again.

When considering the populations of pregnant, lactating and sexually inactive females as well as the proportions of sexually active and inactive males, the same structure was found in 1972 and 1973, in July, month for which data of the two years were available. From these data, I reconstructed the changes in the field mouse population in the boxwood pine-forest during the months of June to November of a fictitious year

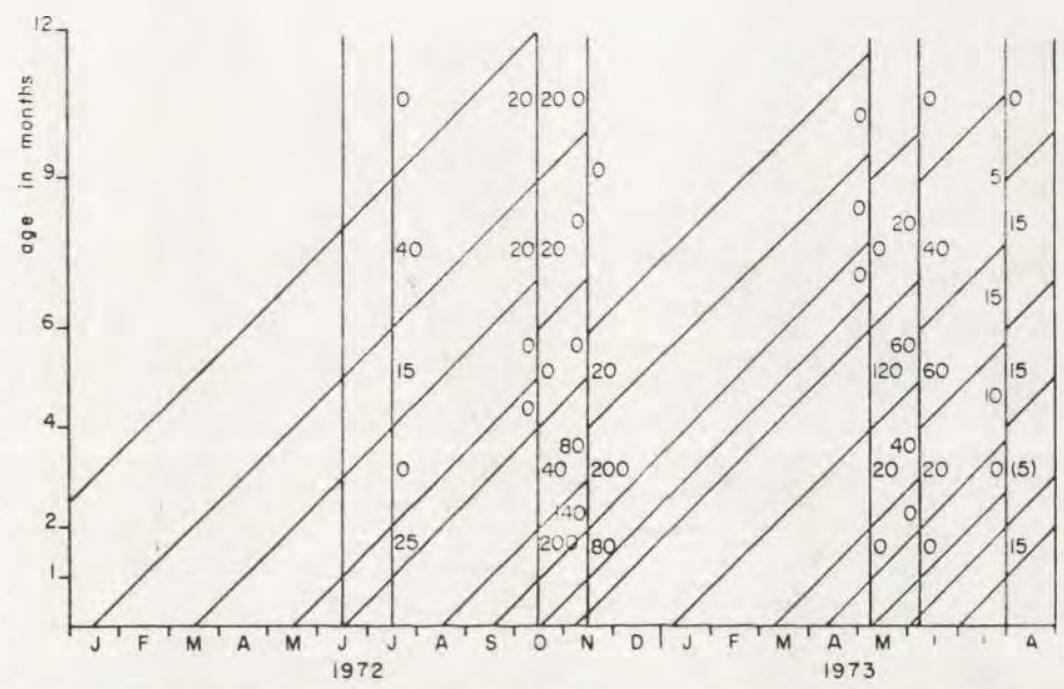

Fig. 1. Representation of fieldmouse cohorts in the boxwood pine-forest.

Each vertical line indicates an immediate representation of the age-class structure. The importance of each age-class is indicated at the right of the corresponding segment. The age-class represents the section of a cohort whose new section and the corresponding new age-class are indicated on the following vertical line. The importance of this new age-class is indicated on the left of the segment. So each cohort is represented by an oblique stripe. Each vertical section of this stripe corresponds to an immediate representation of this cohort. On the other hand, the intersection of this stripe with the horizontal axis gives the birth period of the animals of the cohort.

1973-1972. Figure 2 summarizes the changes in the density of the group of over one month old animals and of various cohorts and the changes in proportion for both sexes of sexually active animals. During the period of reproduction, the first litters would occur at the end of May, the last ones at the end of October. During this period, the turnover is completed.

The breeding has ceased in November (confirmed by the sexual inactivity of the animals) and the fact that the animals trapped late spring were born from October till March assumes, either that the age curve 
according to lens-weight was not reliable (but this is unlikely) or that a second period of reproduction had occurred in winter. Now if we consider the two actual years, there should have heen a period of
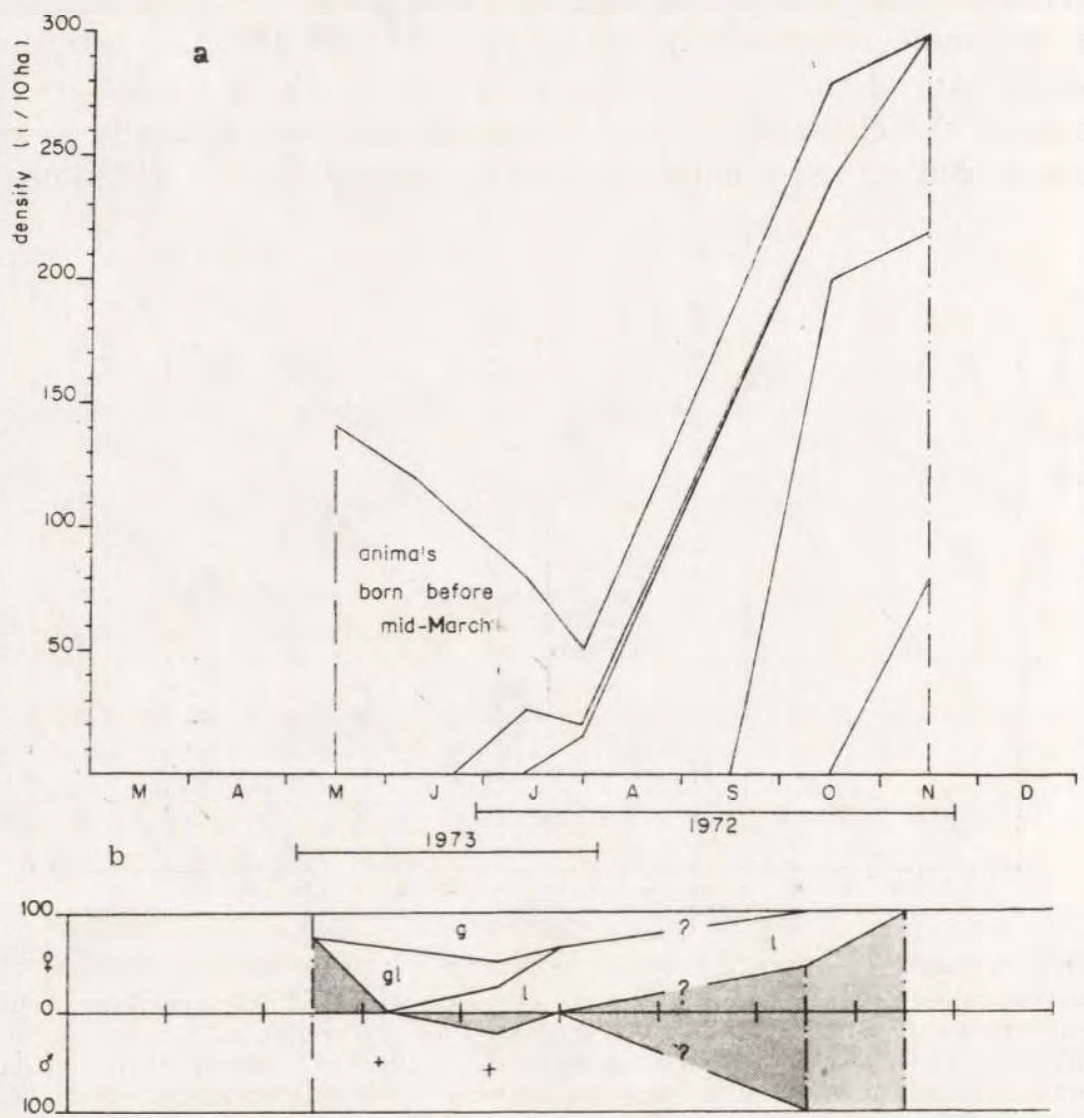

Fig. 2. Fieldmouse density (a) and percentage of sexually active animals (b), from the end of spring till mid-autumn of a fictitious year (73-72) (more than one month old animals).

a - the upper curve represents the variation of the total number of animals per 10 hectares. The other curves delimit the proportions taken in the population by several cohorts which appear in the captures at the date indicated by the contact points of these curves with the horizontal axis (the dates of births are to be located one month earlier).

$\mathrm{b}$ - the percentage of merely pregnant females is marked by $g$, pregnant and lactating ones by $g l$, merely lactating ones by $l$ and sexually inactive ones by a blurred surface; the percentage of sexually active males (strong vascularisation of the epididym) is marked by + and sexually inactive ones by a blurred surface.

parturition from May till October 1972 (the sexual activity of the males having ceased late September-early October); then a hypothetical period of reproduction which would have begun during May. (From the study 
of the captures the beginning of the sexual activity of the males must be located at the end of April-beginning of May). Finally the dissection of the dead animals during a quadrat trapping showed that the sexual activity of the males ceased late September 1973 on the Causse, i.e., at the same period as the year before in the boxwood pine-forest. The study of all line-captured field mice roughly confirms the change noticed in this forest.

In short, we can say that the reproductive cycle seems to have been approximatively the same in all the areas studied in 1972 and 1973. During these two years, there were four periods of reproduction which culminated during the two winters and at the end of the two summers. These four periods were separated by rest periods lasting 1 month or 2 at the most, a rest which may not have been absolute each time.

The density curve of the population is displaced relatively to this cycle: the density was maximum in spring and in autumn and these 2 years. there was a minimum in summer. The difference between these extreme values is very large: the only maximum known (autumn 1972) was sixfold higher than the summer minimum in the boxwood pine-forest (more than fifteenfold in the overall areas studied; the spring maximum was at least tenfold higher).

In another connection, the existence of migrations between the various areas was most likely, in particular between areas where trappings were conducted and areas where trappings were not made because they were apparently little representative or too small but which could constitute refuge areas for the fieldmouse during unfavourable periods, then extension areas during more favourable periods. But this is only a hypothesis.

\section{DISCUSSION}

According to Le Louarn (personal communication) the existence of a density minimum in June is a frequent phenomenon in the fieldmouse in the Brianconnais; Mermod (1965) noticed, in a forest near Lausanne, a large decrease in the population of common fieldmice in June 1964, with 2 density maxima the same year in February and March as well as in September and October. However, he did not find this "minimum" in 1966 whereas it occurred differently in 1965 and 1966 (M e rmod, 1969). Likewise, Le Louarn established in the forest of Fontainebleau such a minimum at the beginning of the summer in 1968 and 1969 but not in 1970 (Le Louarn \& Schmitt, 1972); in this case, the phenomenon was connected to the annual production of beechnuts. On the other hand, Birkan (1968) showed a July minimum in some parts of a pine-forest at Rambouillet, for the same year (1966), 
whereas this minimum did not appear in some other parts. Birkan quoted several other authors w who found minimum values for the numbers of captures in December-January and in June-July and maximum values in February and March and essentially from September till November «.

The annual cycle established in the pine-forest in 1972 and 1973 consequently seems to be very frequent in the common fieldmouse. But it is not possible to generalize this cycle to other years, on the one hand, and to non-trapped areas, on the other.

Concerning the period of reproduction, $\mathrm{B} \mathrm{ir} \mathrm{k} \mathrm{a} \mathrm{n} \mathrm{(l.c.)} \mathrm{noticed} \mathrm{a} \mathrm{ceasing}$ of reproduction from mid-October till mid-November in some areas, whereas there seemed not to have been any ceasing in some other areas. Le Lou a r n (personal communication) noticed an onset of reproduction at the beginning of May during most of the years in the Brianconnais.

These reproductive cycle data are analogous to those found in the study pine-forest in 1972 and 1973. But in this case too, the length of the reproductive period may vary from one year to another and it is not always easy to establish an eventual relationship with environmental factors (quoted in the literature). However, there is very often only one annual period of reproduction and the existence of 2 periods of nonactivity which seems to be confirmed during at least 2 years in the boxwood pine-forest does not seem to be very frequent in most of the other areas. At the present time, it is not possible to determine if these two annual periods, which are perhaps an adaptation to the climate, can be found the other years or not.

Another problem can be raised: the cohort of animals born in July, which constitutes the group of the older animals in autumn, seems smaller in August and in September, a period when it should have been particularly well represented in the captures. This probably partly accounts for the August minimum. (The minimum of late June could of course be explained quite logically by the normal displacement of the onset of sexual activity and the arrival of trappable young animals). The appearance of a very low density of fieldmice during the summer is far from being a new problem to which many solutions were suggested.

The behaviour of the fieldmice towards the traps might have changed ( $\mathrm{T}$ a $\mathrm{n}$ t o $\mathrm{n}, 1965)$, but the diet cannot be directly concerned in the case of traps used without any bait.

The hypothesis of migrations remains the most likely. According to the latter, M ill e r (1958) explained a very marked fall in the fieldmouse density in July 1950 (Wytham Wood). In that case, it really seemed to be a complete "shift" in the adjoining wheat field. Besides, this spontaneous change of vital area is a well established phenomenon (Crawley, 1960; B ovet, 1963) although this displacement represents 
less than 200 meters (besides the field devices available do not permit the establishment of extensive movements).

The presence of sexually active fieldmice and above all the presence of pregnant then lactating females in most of the study areas (in particular in forestrial areas) make the idea of a complete immigration most unlikely. We may assume the existence of the following scheme: Emigration in summer out of most of the study areas. One of the causes may be the scarcity of food available between the metamorphosis of most of the insect larvae (main source of the fieldmice insectivorous diet according to the already quoted authors) and the ripening of seeds in autumn; immigration in autumn from the centres of activity constituted in summer and created by the simple "demographical pressure or by the fact that these centres of activity have become unfavourable areas.

It is not possible to go any further without more complete information, but it seems necessary to emphasize the fact that the mere study of some biotopes of a region, even if they cover the largest surfaces is insufficient for a through understanding of the population dynamics of this region because of the important immigration movements which might exist between the neighbouring unstudied areas and the studied ones.

\section{REFERENCES}

1. Birkan M., 1968: Répartition écologique et dynamique des populations d'Apodemus sylvaticus et Clethrionomys glareolus en pinède à Rambouillet, La Terre et 1a Vie, 22: 231-273.

2. Bovet J., 1963: Observations sur la sédentarité et le domaine vital du Mulot sylvestre, (Apodemus sylvaticus) en Camargue. La Terre et la Vie, 110: 266-279.

3. Crawle y M. C., 1960: Movements and home range of Clethrionomys glareolus Schreber and Apodemus sylvaticus L. in north-east England. Oikos, 20: $310-319$

4. Eberhardt L. L., 1971: Population analysis [In: $»$ Wildlife management Techniques«, Ed. Giles R. H., Jr.]. The Wildlife Society. 457-495.

5. Le Louarn H., 1971: Determination de l'âge par la pesée des cristillins chez quelques espèces de Rongeurs. Mammalia, 35: 636-643.

6. Le Lou a r n H. \& S chmitt A., 1972: Relations observées entre la production de faînes et la dynamique de population du mulot Apodemus sylvaticus L. en forêt de Fontainebleau. Ann. Sci. Forest. 30: 205-214.

7. Mermod C., 1965: Fluctuations d'une population de Mulots en 1964. Rev. suisse Zool., 72: 624-629.

8. Mermod C., 1969: Ecologie et dynamique des populations de trois Rongeurs sylvicoles. Mammalia, 33: $1-57$.

9. Miller R. S., 1958: A study of a Wood mouse population in Wytham Woods, Berkshire, J. Mammal., 39: 477-493.

10. Spitz F., Le Louarn H., Poulet A. R., Dassonville B., 1974: Standardisation des piégeages en ligne pour quelques espèces de Rongeurs. La Terre et la Vie, 28: 564-578. 
11. Tanton M. T., 1965: Problem of live-trapping and population estimation for the wood-mouse Apodemus sylvaticus L. J. Anim. Ecol. 34: 1-22.

12. Treussier M., 1975: Contributions à l'étude du peuplement micromammalien de l'Aigoual et des Causses. Thèse 3e cycle. Université des Sciences et Techniques du Languedoc (Montpellier II).

Accepted, May 20, 1976.

Michel TREUSSIER

\section{DYNAMIKA POPULACJI MYSZY ZAROSLOWEJ}

\section{Streszezenie}

Dane demograficzne dotyczą populacji myszy zaroślowej, Apodemus sylvaticus (L i n n a u s, 1758) w borze sosnowym bukszpanowym, w 1972 i 1973. Zastosowano tabele życia dla poszczególnych kohort (Ryc. 1). Zabijanie schwytanych zwierząt dostarczało precyzyjnych informacji o aktywności płciowej i wieku zwierząt. Liczebność była bardzo niska w obu okresach letnich. Znacznie wyższa była jesienią i wiosną. Wykazano przerwę w rozmnażaniu późną jesienią; sugeruje się drugą przerwę na przełomie zimy i wiosny (Ryc. 2). Młode rodzily się zarówno w okresie od maja do października, jak i zimą. Nie wyklucza się możliwości migracji. 